\title{
Relationship between shipping amounts of olive flounder aquacultured from Jejudo and the reported events of acute food poisoning by Kudoa septempunctata in 2015, South Korea: an ecological study
}

\author{
Jong-Myon Bae \\ Department of Preventive Medicine, Jeju National University Scool of Medicine, Jeju, Korea
}

\begin{abstract}
OBJECTIVES: Confirmation of Kudoa septempunctata (K. septempunctata) as the pathogenic agent causing acute food poisoning remains under debate owing to inconsistencies in the reproducibility of experimental evidence. Higher intake of olive flounder infected with $K$. septempunctata would result in increased diagnosis of food poisoning by K. septempunctata, if the latter was one of the causal agents of acute food poisoning. The aim was to evaluate the relationship between the shipping amount of olive flounder aquacultured from Jejudo and the incidence of $K$. septempunctata food poisoning in 2015, Korea.
\end{abstract}

METHODS: Data of shipping amounts between March 2014 and February 2016 and of monthly reported events of Kudoa food poisoning were taken from Jejudo Fish-Culture Fisheries Cooperatives and Korea Centers for Disease Control and Prevention, respectively. Non-parametric correlation analyses were conducted.

RESULTS: Shipping amounts indicated the seasonal changes according to variation of consumption. Spearman's rho and Kendall's tau-a between the monthly shipping amounts and the reported events in 2015 were $0.39(\mathrm{p}=0.21)$ and $0.27(\mathrm{p}=0.20)$, respectively.

CONCLUSIONS: An independent relationship was noted between the shipping amount and the reported events, which contrasted with the claim that the virulence of $K$. septempunctata caused acute food poisoning.

KEY WORDS: Virulence, Food parasitology, Parasitic intestinal diseases, Myxozoa, Ecological bias

\section{INTRODUCTION}

In December 2012, it was first claimed internationally that $\mathrm{Ku}$ doa septempunctata (K. septempunctata) found in some of the cul-

\section{Correspondence: Jong-Myon Bae}

Department of Preventive Medicine, Jeju National University

School of Medicine, 102 Jejudaehak-ro, Jeju 63243, Korea

E-mail:jmbae@jejunu.ac.kr

Received: Aug 13, 2017 / Accepted: Sep 6, 2017 / Published: Sep 6, 2017

This article is available from: http://e-epih.org/

(C) This is an open-access article distributed under the terms of the Creative Commons Attribution License (http://creativecommons.org/licenses/by/4.0/), which permits unrestricted use, distribution, and reproduction in any medium, provided the original work is properly cited.

(C) 2017, Korean Society of Epidemiology tured olive flounders aquacultured in Jejudo, South Korea (hereafter Korea) [1], and had caused food poisoning [2,3]. Subsequently, the Korea Centers for Disease Control and Prevention (KCDC) reported 11 events occurred in 2015 [4]. In that report, the K. septempunctata food poisoning was defined as "those where the $18 \mathrm{~S}$ ribosomal RNA gene of $K$. septempunctata had been detected in the vomit or excreta of patients with acute food poisoning symptoms who reported consuming sliced raw fish of olive flounders."

The virulence of K. septempunctata was first noticed from experiments using 4-5 days old Deutschland, Denken, and Yoken mice [2]; however, other researchers were unable to reproduce this pathogenesis upon conducting the same experiments [5-7]. As such, the causality of $K$. septempunctata food poisoning has remained controversial due to irreproducibility of study results [8]. Moreover, it was suggested that the 11 events of food poisoning 
that reported in 2015 might not have been caused by K. septempunctata. First, because epidemiologic characteristics, including incubation period and clinical symptoms suggested that the food poisoning could be caused in combination with either Staphylococcus aureus or Bacillus cereus; especially because of the difficulty in detecting toxins and pathogenic agents for both types of food poisoning during the epidemiological investigations [9]. Second, owing to the differences in the monthly distribution of the 11 events. About $75 \%$ of K. septempunctata food poisoning in Japan occurred between August and November [3], whereas a total of 4 events had reported in Korea during the same period with a proportion of $36.3 \%$, showing only half compared to Japan [4]. In addition, 4 events reported only during May in Korea, while there was no event in June and July, so that the validity of the definition for K. septempunctata food poisoning made by KCDC seemed doubtful.

On the other hand, as there were differences in reported events depending on the month, correlation with monthly variation of sales amounts of olive flounders aquacultured from Jejudo needed to be considered [9]. In other words, if K. septempunctata were the pathogenic myxozoa causing the acute food poisoning, there would be a higher risk of food poisoning events when the intake of olive flounder aquacultured from Jejudo increased. Thus, this study aimed to investigate the correlation between the monthly distribution of the reported events of $K$. septempunctata food poisoning reported by the KCDC in 2015, and the monthly shipping amounts of olive flounder that Jejudo Fish-Culture Fisheries Cooperatives (http://www.jaf-suhyup.co.kr/, hereafter JFC) supplied to the Korean domestic markets during the same period. It was expected that the present ecological study would add evidence to evaluate the hypothesis that $K$. septempunctata was the pathogenic myxozoa causing acute food poisoning.

\section{MATERIALS AND METHODS}

The JFC kindly provided the monthly shipping data for olive flounders aquacultured from Jejudo between March 2014 and Feb- ruary 2016 (Appendix 1). To investigate the trend of seasonal shipping amounts, the data were reclassified into March-May, June-August, September-November, and December-February in the next year.

Information about $K$. septempunctata events was based on the 2015 report on K. septempunctata food poisoning published by the KCDC in 2016 [4]. These 11 events summarized by month were the first reported Korean events where the KCDC interpreted national $K$. septempunctata food poisoning reports.

To investigate the correlation between shipping amounts during each month of 2015 and K. septempunctata food poisoning events during same time, coefficients for non-arametric methods, Spearman's rho and Kendall's tau-a, were calculated with a pvaule $=0.05$ significance level. To evaluate the delay effect, crosscorrelation of time series analysis was calculated; considering that there was 12 months of data, a 3 months time delay was set. These analyses were conducted by using Stata version 14 (StataCorp., Collage Station, TX, USA).

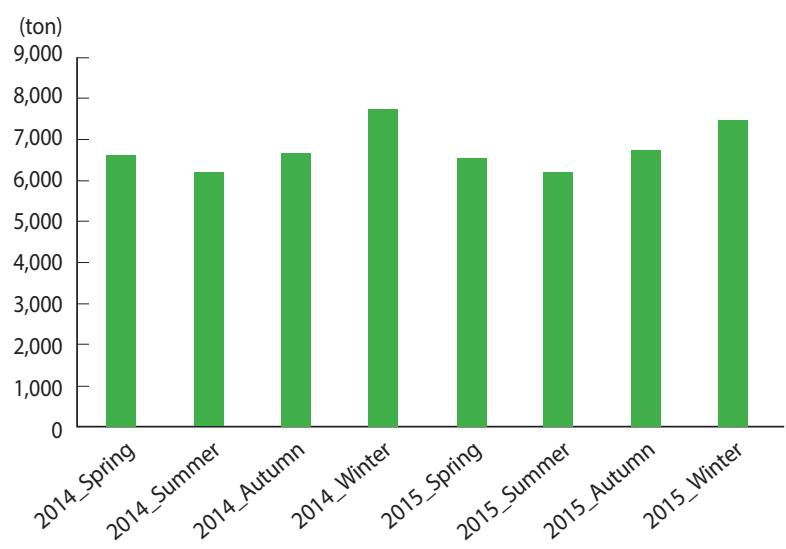

Figure 1. Seasonal shipping amounts of olive flounder from Jejudo between Spring 2014 and Winter 2015.

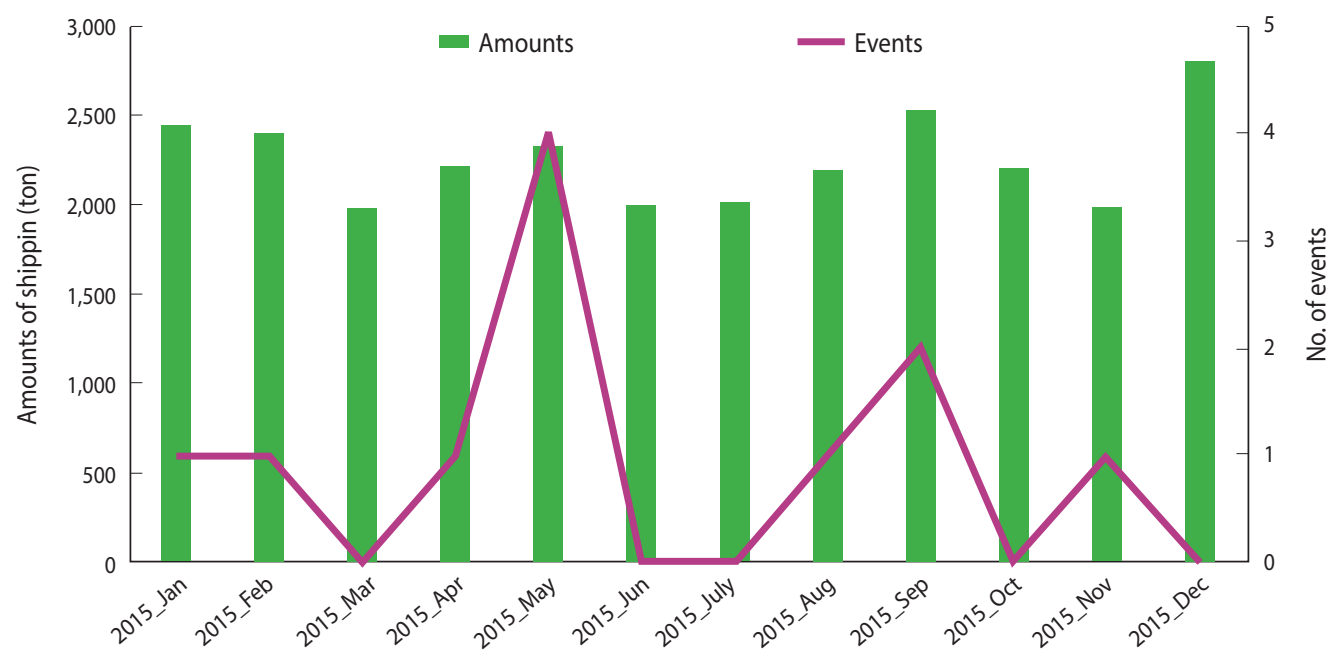

Figure 2. Seasonal shipping amounts of olive flounder from Jejudo and incidence of $K$. septempunctata food poisoning in 2015 , Korea. 
Table 1. Cross-correlation coefficients by time lags

\begin{tabular}{lc}
\hline Time lag $(\mathrm{mo})$ & Cross-correlation coefficient \\
\hline-3 & 0.000 \\
-2 & 0.077 \\
-1 & 0.000 \\
0 & 0.237 \\
1 & 0.000 \\
2 & -0.007 \\
3 & 0.000 \\
\hline
\end{tabular}

\section{RESULTS}

When seasonal shipping amounts by JFC in 2014-2015 were checked, there were seasonal changes in the shipping amount in the order of winter-fall-spring-summer (Figure 1). In 2015, when monthly shipping amounts and the events by month were considered together, there was no event in December when the shipping amount was highest, while there was 1 event in November when there was lowest shipping amount (Figure 2). In addition, May had the highest number of events with the fifth highest shipping amount. All non-parametric correlation analyses between shipping amount and number of events found that they were independent with a $\mathrm{p}=0.05$ (Spearman's rho $=0.39, \mathrm{p}=0.21$; Kendall's tau- $\mathrm{a}=0.27, \mathrm{p}=0.20$ ). In addition, cross-correlation found no correlation depending on delay by month (Table 1).

\section{DISCUSSION}

The present study identified that monthly shipping amounts of olive flounders aquacultured in Jejudo in 2015, and the events of K. septempunctata food poisoning in the same month were mutually independent. The results of this ecological study had two meanings. First, K. septempunctata food poisoning as defined by the KCDC needs to be reviewed. Second, accepting the present definition would be supporting the evidence that $K$. septempunctata is not a pathogenic myxozoa causing acute food poisoning in humans, but just a parasite in olive flounders.

The KCDC interpreted that the monthly variation of reported events was due to the difference in detection rate depending on sea water temperature [4]. However, it was claimed that K. septempunctata was detected throughout the year regardless of sea water temperature [10]. Furthermore, it was also reported that $K$. septempunctata was not detected in wild olive flounders [11]. Therefore, it seems unlikely that the seasonal variation in events was attributable to the difference in sea water temperature.

On the other hand, most events occurred during the summer and the fall in Japan [3], whereas there was no event during the summer (July and August) and the highest was in spring (May) in Korea [4]. Therefore, it would be more reasonable to interpret the difference based on the variation of chance for the intake of sliced raw olive flounders by month, instead of change in water temperature. The present study also found that seasonal difference was not attributable to the variation of shipping amounts.

The present study had four major limitations. First, there may be differences between the shipping amount of olive flounders used for analyses in this study and the actual amounts consumed. However, cultured olive flounders to be used for sliced raw fish needed to be delivered alive to the ultimate consumers, so shipping amounts were determined by amounts ordered. Thus, it can be considered that shipping amounts and consumed amounts should be directly proportional, albeit not exactly the same. This was overcome by correlation analyses. Second, if there were time gaps between shipping and intake, there would be no correlation. However, olive flounders were mostly consumed as sliced raw fish, so in restaurants they tend to be consumed as soon as possible in order to be provided in the freshest state. While the time gap may be a few days, it hardly goes beyond a month. In addition, the present study was analyzed by month, not by day, and the cross-correlation analysis confirmed that there were no variations dependent on delay duration. Third, this study used the number of events for K. septempunctata food poisoning from the report by the KCDC, while numbers of patients per each event were not used. K. septempunctata food poisoning was caused by a common cause [4], in which there were various numbers of patients per event. Thus, it was regarded more reasonable to use number of events for ecological analysis rather than number of patients. Fourth, this study was designed as an ecological analysis, in which ecologic fallacy by using group data, instead of individual data, could be introduced [12]. Thus, the results of this study should not claim that causality was revealed, but instead, should propose a new hypothesis [13]. While previous studies claimed that $K$. septempunctata could be pathogenic myxozoa causing acute food poisoning, the present study suggested that epidemiologic study should be conducted to find a more valid causality.

\section{ACKNOWLEDGEMENTS}

The author would like to thank Dr. Sung-Mi Kim, a team leader of Jejudo Fish-Culture Fisheries Cooperatives for providing shipping amounts data.

\section{CONFLICT OF INTEREST}

The author has no conflicts of interest to declare for this study.

\section{SUPPLEMENTARY MATERIAL}

Supplementary material (Korean version) is available at http:// www.e-epih.org/.

\section{ORCID}

Jong-Myon Bae: http://orcid.org/0000-0003-3080-7852 


\section{REFERENCES}

1. Matsukane Y, Sato H, Tanaka S, Kamata Y, Sugita-Konishi Y. Kudoa septempunctata n. sp. (Myxosporea: Multivalvulida) from an aquacultured olive flounder (Paralichthys olivaceus) imported from Korea. Parasitol Res 2010;107:865-872.

2. Kawai T, Sekizuka T, Yahata Y, Kuroda M, Kumeda Y, Iijima Y, et al. Identification of Kudoa septempunctata as the causative agent of novel food poisoning outbreaks in Japan by consumption of Paralichthys olivaceus in raw fish. Clin Infect Dis 2012;54:10461052.

3. Sugita-Konishi Y, Sato H, Ohnishi T. Novel foodborne disease associated with consumption of raw fish, olive flounder (Paralichthys olivaceus). Food Saf 2014;2:141-150.

4. Korea Centers for Disease Control and Prevention. Case reports of Kudoa food poisoning in 2015; 2016 [cited 2017 Aug 11]. Available from: http://cdc.go.kr/CDC/notice/CdcKrTogether0302.jsp? menuIds $=$ HOME001-MNU1154-MNU0005-MNU0088\&cid $=$ 71877 (Korean).

5. Guo Q, Jia L, Qin J, Li H, Gu Z. Myxozoans and our dinner table: pathogenicity studies of Myxobolus honghuensis (Myxosporea: Bivalvulida) using a suckling mice model. Foodborne Pathog Dis 2015;12:653-660.

6. Ahn M, Woo H, Kang B, Jang Y, Shin T. Effect of oral administra- tion of Kudoa septempunctata genotype ST3 in adult BALB/c mice. Parasite 2015;22:35.

7. Jang Y, Ahn M, Bang H, Kang B. Effects of Kudoa septempunctata genotype ST3 isolate from Korea on ddY suckling mice. Parasite 2016;23:18.

8. Chung YB, Bae JM. Is there evidence that Kudoa septempunctata can cause an outbreak of acute food poisoning? Epidemiol Health 2017;39:e2017004.

9. Lee SU. Analysis of Kudoa septempunctata as a cause of foodborne illness and its associated differential diagnosis. Epidemiol Health 2017;39:e2017014.

10. Ohnishi T, Furusawa H, Sako H, Ototake M, Fukuda Y, Yoshinari $\mathrm{T}$, et al. Studies on seasonal changes in occurrence of food-borne disease associated with Kudoa septempunctata. Jpn J Food Microbiol 2013;30:125-131 (Japanese).

11. Song JY, Choi JH, CHoi HS, Jung SH, Park MA. Monitoring of Kudoa septempunctata in cultured olive flounder and wild fish in Jeju Island during 2012. J Fish Pathol 2013;26:129-137 (Korean).

12. Wakefield J. Ecologic studies revisited. Annu Rev Public Health 2008;29:75-90.

13. Lee SU. Analysis of Kudoa septempunctata as a cause of foodborne illness and its associated differential diagnosis. Epidemiol Health 2017;39:e2017037r. 
Appendix 1. Shipping amounts of olive flounder from Jejudo from January 2014 to February 2016

\begin{tabular}{lc}
\hline Time & Amount (ton) \\
\hline 2014_Jan & 1,858 \\
2014_Feb & 2,038 \\
2014_Mar & 2,262 \\
2014_Apr & 2,143 \\
2014_May & 2,225 \\
2014_Jun & 2,197 \\
2014_July & 2,066 \\
2014_Aug & 1,922 \\
2014_Sep & 2,099 \\
2014_Oct & 2,564 \\
2014_Nov & 2,002 \\
2014_Dec & 2,906 \\
2015_Jan & 2,443 \\
2015_Feb & 2,403 \\
2015_Mar & 1,986 \\
2015_Apr & 2,220 \\
2015_May & 2,335 \\
2015_Jun & 2,000 \\
2015_July & 2,013 \\
2015_Aug & 2,199 \\
2015_Sep & 2,531 \\
2015_Oct & 2,214 \\
2015_Nov & 1,988 \\
2015_Dec & 2,809 \\
2016_Jan & 2,290 \\
2016_Feb & 2,371 \\
\hline & \\
\hline
\end{tabular}

